\title{
Muhasebe Denetiminde Nesnelerin İnterneti: Stok Döngüsü
}

\author{
İlkay Ejder ERTURAN* \\ Emre ERGIN**
}

\section{$\ddot{O Z E T}$}

Şirketlerin faaliyetlerini küreselleşme, yoğun rekabet ortamı ve teknolojik gelişmeler şekillendirmektedir. Nesnelerin İnterneti yeni bir kavram olarak ortaya çıkmıştır. Bu kavram ile küresel bir iletişim ağ olan internetin bilgiyi sadece insanlardan değil nesnelerden de almast ve böylece topladı̆̆ bilgiyi yorumlayıp diğer nesnelere ve insanlara iletmesi ifade edilmektedir. Günümüzde internete bilgi girişlerinin neredeyse tamamı insan kaynaklıdır. İnsanoğlunun zamanının klsitlllı̆̆l, bilgi eksikliği ve hatalı bilgi girme olasılığı gibi gerekçelerden dolayı internetten sağlanan yarar sınırlıdır. Internetin nesneler ile sürekli bağlantılı olarak sağlayacă̆ bilgiler ile kendi kendini yönetir bir duruma kavuşması sonucunda hem gündelik hayatta hem de şirketlerin satın alma, üretim, satış, bakım ve onarım gibi yönetim süreçlerinde etkinlik ve verimlilik artacaktır. Bu çalışmada, geleceğin işletmelerinde denetim, denetçinin rolü ve nesnelerin interneti kavramının denetim alanına uygulanabilirliği stok döngüsü kapsamında açıklanmaktadır. Nesnelerin internetinden yararlanılması sayesinde, insana özgü hataların azaltulması, denetim kalitesinin arttırılmast, zamanın etkin kullanılması ve maliyetten tasarruf edilmesi ile rekabet üstünlüğ̈̈ kazanılması olanaklıdır.

Anahtar Kelimeler: Nesnelerin İnterneti, Stoklar, Bağımsız Denetim, Muhasebe.

JEL Siniflandirması: M42, M41, M11.

\section{Internet of Things In Auditing: Inventory Cycle}

ABSTRACT

Globalization, intensive competitive environment and technological improvements shape the activities of companies. The Internet of Things has emerged as a new concept. This concept states that the global Internet should not only collect information from humans but also from things in order to analyze the information collected and transmit it to other things as well as humans. The data input processing to Internet derives mostly from humans. However, due to reasons such as the limited time and lack of information of people, and the possibility of entering erroneous information during processing, the benefits provided by the Internet are limited. The continuous connection with objects and autonomous management of the Internet will increase the efficiency and effectiveness in the everyday life and corporations' activities such as purchase, production, sales, repair and maintenance. This paper examines the transformation in audit, the role of the auditors in future companies and the application of the Internet of things concept to inventory cycle in auditing. The utilization of the Internet of things will decrease human derived mistakes, improve audit quality, and help gain competitive advantage thanks to time and cost minimization.

Keywords: Internet of Things, Inventory, Independent Auditing, Accounting.

Jel Classification: M42, M41, M11.

\footnotetext{
*Yrd.Doç.Dr. İlkay Ejder Erturan, Düzce Üniversitesi, Çilimli Meslek Yüksekokulu, Muhasebe ve Vergi Bölümü, ilkayerturan@duzce.edu.tr.

** Doç.Dr. Emre Ergin, Kocaeli Üniversitesi, İzmit Meslek Yüksekokulu, Muhasebe ve Vergi Bölümü, emre.ergin@kocaeli.edu.tr.
} 


\section{GİRiş}

Gelişmiş ülkelerin en önemli itici gücü olan yüksek teknolojiyi kullanma becerisi ile yeni kavramlar ortaya çıkmaktadır. Bu yeni kavramlar şirketlere firsatlar sunmaktadır. 19. yüzyıla kadarki sürecin tamamındaki teknolojik gelişmelerde elde edilen kazanımlar, 20. yüzyılda katlanmıştır (Yüksek, 2015). Günümüzde ise her on yılda elde edilen birikim, bir önceki yüzyılda elde edilen kazanımları katlamaktadır. Küreselleşme ile birlikte hızla yayılan teknolojik gelişmeler rekabet ortamını etkilemektedir. Geleneksel iş yapma yöntemleri, rekabet etme gücünün düşmesine neden olmaktadır. Modern toplumların karşılıklı bağımlılığı artarak ekonomiye dayalı sorunların çözümünün şirketlerin faaliyetlerinin birbirine bir ağ ile bağlanarak koordine edilmesi olarak gözükmektedir (Heilbroner ve Milberg, 2011: 75). Şirketlerin faaliyetlerini sürdürmesi için, teknolojik gelişmeleri yakından izlemesi ve bu gelişmelerden kendisine uygun olanları uyarlaması gerekmektedir. İçinde bulunulan çağ için bilgi çağı, teknoloji çağı ve hız çağı gibi farklı tanımlamalarda bulunulmaktadır. Bu hızlı gelişim sürecinde internetin kullanımı ve etkisi önemli bir paya sahiptir.

Çok yakın zamanda ortaya çıkan Nesnelerin İnterneti (NI) kavramı ile internetin sadece insanlarla değil nesnelerle de iletişime geçerek internetin yarattığı küresel etkiden daha önemli ve büyük bir değişime Nİ'nin yol açması beklenmektedir (Ashton, 2009).

$\mathrm{Bu}$ gelişmelerin ardından internet ve iletişim kavramlarının anlamında genişleme meydana gelmiştir. İletişim, geleneksel yaklaşımın taşıdığı anlamı aşmakta, fiziksel üretim sistemlerinin kendi arasındaki iletişimi ve fiziksel üretim sistemleri ile insanlar arasındaki iletişimi kapsamaktadır. Sensörler ve uyarıcılar aracıllğıyla makine, ürün, sistemler, süreçler ve insanlar birbirlerine bağlanmaktadır. Böylelikle nesneler ve insanlar birbirleri ile sürekli iletişimde kalarak, birbirlerini gerektiğinde uyarmakta ve böylece şirketlerde satın alma, üretim ve satış gibi tüm süreçlerin sağlıklı bir şekilde tamamlanmasını sağlamaktadır. İçinde bulunulan üçüncü sanayi devriminden dördüncü sanayi devrimine doğru alınan yolda Nİ'nin desteğiyle üretimin her alanında fiziksel nesnelerin birbirleriyle ve insanlarla iletişime geçmesi öngörülmektedir.

Denetim ve danışmanlık hizmeti veren uluslararası kurumların araştırmalarında, dördüncü sanayi devrimi olarak da adlandırılan endüstri 4.0 ile sağlanacak otomasyon ile satışların 2013 ile 2018 yıllarında \%22 artarak yaklaşık 200 milyar Euro'ya yükseleceği öngörülmektedir. Endüstri 4.0'ın uygulamasında, NI sanayiyi kökten değiştirecektir. Bu doğrultuda, dijital fabrikalarda kullanılan akıllı makineler, dünya genelindeki diğer makinelerden topladığı bilgilerle komutlarını iletecek şekilde tasarlanmaktadır. Bu süreçte, veriler gerçek zamanlı olarak yatay ve dikey olarak iletişimde olacaktır. Bu entegrasyon ve rekabet süreci tedarikçi, alıcı ve distribütörlerin de hızla bu ağa girmelerini sağlayacaktır (Sarı, 2016). Nİ ağının öncelikle finans, sağlık, havacıllk ve otomotiv sektörlerinde maliyet üstünlüğü sağlayarak satışlara, ekonomik büyümeye ve istihdama etki etmesi beklenmektedir (Cohen, 2016). 
Dördüncü sanayi devrimi ile birlikte değişen dünya ve ticaret anlayışı muhasebe ve denetim alanlarında farklılık oluşturacaktır. Bu çalışmanın ikinci bölümünde Nİ kavramı ve meydana gelen bu değişimin şirketleri gelecekte nasıl etkileyeceği tartışılmaktadır. Üçüncü bölümde Nİ ile muhasebe denetimi alanında yaşanacak değişimlere odaklanılmaktadır. NI'nin etkileri üretim şirketlerindeki stoklar hesap grubuyla sınırlandırılarak dördüncü bölümde incelenmektedir. Beşinci ve son bölüm olan sonuç bölümünde ise bu makalede ortaya çıkan yeni denetim yaklaşımı ve geleceğe yönelik yansımalar vurgulanmaktadır.

\section{NESNELERİN İNTERNETİ}

Bilgi dolaşımının hızlanmasına katkı yapan internet olgusundan hareketle yeni bir kavram ortaya konulmuştur: Nesnelerin İnterneti. Nİ kavramı ilk defa Ashton tarafindan 1999 yılında bir özel şirkete yapılan sunum sırasında ifade edilmiştir (Ashton, 2009). Ashton, günümüzde internetin, insanların bilgisayarlara yaptıkları veri girişine bağımlı olduğunu belirtmektedir. Ancak insanların zamanı, bilgisi ve veri girişinin doğruluğu sınırlıdır. İnternet, insanlardan gelen fikirleri tanımaktadır. İnternet, dünyada var olan fiziksel nesneler (şeyler) hakkında çok az bilgiye sahiptir. İnternetin bilgiyi sadece insanlardan değil, nesnelerden de toplaması gerektiği vurgulanmaktadır. Böylece insandan kaynaklanan hata, zarar ve maliyet azalacaktır. Ayrıca internet nesnelerden topladığı bilgi sayesinde, nesnelerin ne zaman değiştirilmesi, bakım yapılması, geri çağrılması gibi birçok konuda zamanında bilgi sahibi olunacaktır.

Heil vd. (2007), Nİnin bağlama dayalı niteliğine vurgu yapmışlardır: Nİ bağlamı, sensörler tarafından ilgili nesneler, ilgisiz nesneler ve ilgili nesneler arasındaki ilişkiyi okumasına göre değişmektedir. Avrupa'da oluşturulan bir komisyonda ise Nİ geleceğin interneti olarak da değerlendirilmiş ve kendi kendini yapılandırabilen, kimliği ve aklı olan fiziksel ve sanal şeylerin bir bütün olduğu bir ağ olarak tanımlanmıştır (Guillemin ve Friess, 2009). Chui vd. (2010) Nİ'yi, fiziksel cisimlerin içine yerleştirilmiş sensör ve aktüatörlerin kablolu veya kablosuz olarak internete bağlanması olarak tanımlamaktadır. Atzori vd. (2010), nesneler ve internete üçüncü bir boyut daha ekleyerek, Nİyi, nesneler, internet ve semantik boyutlarının kesişim alanı olarak tanımlamaktadır. Ning ve Hu (2012) Nİ ile akıllanma ve bilgi gelişimi döneminin başladığını ve Nİ'nin eğitimde bir alan olarak açılarak öğretilmesi gerektiğini ifade etmişlerdir. Leary (2013) Nİ, büyük veri ve işaretlerin interneti kavramlarının gelişimi ile bu kavramlar arasındaki ilişkiyi araştırmıştır. Sensöre dayalı bilgi ile insan kaynaklı bilginin entegre edilmesinin daha değerli bilgi sağladığını göstermiştir.

Nİ kavramının anlamı için tek bir tanımda uzlaşı olmamasına karşın, Nİ bütünleşik bir ağ üzerinde her şeyi ve herkesin birbirine bağlanması olarak tanımlanabilir. Nİ fiziki bir varlığı olan nesnelerin başka nesnelerle ve başka veri ağlarıyla bağlantılı olduğu bir iletişim şebekesidir. Nİ şebekesine yazılım programları ve sensörler aracılığıyla canlı ve cansız her şey bağlanabilir. Bazı büyük şirketler müşterilerinin tüketim alışkanlıklarını bu şekilde izleyerek satın alma olasılığı göreceli olarak daha yüksek olan ürünlerin pazarlamasını 
yönetmektedir. Şirketlerin yönetim süreçleri Nİ şebekesine bağlanarak üretim için gereken kaynakların lojistiği ve üretimin kesintisiz sürmesi sağlanabilir. Ekonomik ve sosyal hayatın her aşamasında Nİ'den yararlanılması olanaklıdır. Bu veri ağı, hayatın her anından, milyarlarca veri toplayarak, anlamlı bilgilere dönüştüren teknolojik cihazlar ile doludur. Nesnelerin dünyasında hedeflenen fayda, anlamlandırılmış bu veri ile insan hayatının kalitesini arttırmak, zamanı etkin kullanmak (tasarruf) ve güvenlik (izleme) sağlamaktır (Yüksel, 2015). Ní ile uygarlığın temsilcisi şehirler, daha tempolu ve planlı yaşama ayak uyduran ak1llı şehirlere (Zanella ve Vangelista, 2014) dönüşmektedir. Bu dönüşüm beraberinde hayatı kolaylaştıran birçok firsatı insana ve şirketlere sunmaktadır.

Nİ hayatı her anlamıyla çok hızlandırmış ve dördüncü sanayi devrimine etki edecek en büyük güç olarak görülmektedir. Sanayi devrimleri toplumların kaderlerini değiştiren olaylardır. Su ve buhar enerjisini daha verimli kullanan mekanik iş makinelerinin 18. yüzyılın sonlarında yapımıyla birinci sanayi devrimi başlamıştır. İkinci sanayi devrimi, Ford Motor şirketinin kurucusu Henry Ford'un üretim hattı tasarımı sonucunda elektrik enerjisinin seri üretimde kullanılmaya başlamasıyla ortaya çıkmıştır. Üretimde bilişim teknolojilerinin, mekanik ve elektronik teknolojiler ile birlikte kullanımı ile ortaya çıkan dijital teknolojiler ve programlanabilir yönetim sistemleri 1970’lerde üçüncü sanayi devriminin başlamasını sağlamıştır.

Dördüncü sanayi devriminde farklı sistemlerin birbiri ile entegre olması ve böylece bir bütünün parçası gibi çalışması planlanmaktadır. Bir üretim şirketindeki sistemlerin entegrasyon ile şirket içerisindeki üretim dışı departmanların dikey entegrasyonu (araştırma ve geliştirme, üretim, bilgi işlem, mali işler, satış ve pazarlama vb.) ve yatay entegrasyon (satıcı, lojistik şirketler) ifade edilmektedir. Ürünün müşteri tarafından sipariş edilmesinden kendisine teslim edilmesine kadar geçen süreçte siber-fiziksel sistemler devreye girmektedir (Duda, 2015). Siber-fiziksel sistemler, internet ve kullanıcıların entegre olarak, fiziksel ve yazılım parçalarının birbiriyle örüldüğü ve bilgisayar tabanlı algoritmalar tarafından kontrol edilen veya yönetilen mekanizmalar olarak tanımlanmaktadır (Baheti ve Gill, 2011). Dördüncü sanayi devriminde üretim süreçleriyle ilgili verinin bulut bilişim ve veri analizi gibi yöntemler ile sistemin kendisi tarafından toplanarak planlama ve kontrol süreçlerine entegre edilmesi ön plana çıkmaktadır.

Endüstri 4.0 ile ürünlerin pazara hızlı sunumu; insan, makine ve sistemlerin birbiri ile bağlanarak fabrikaların verimliliğinin artması beklenmektedir. Türkiye'nin de otuz yıl içinde bu süreci tamamlayacağı öngörülmektedir (Sarı, 2016). Endüstri 4.0 kavramı ortaya çıkmadan önce Siemens gibi bazı şirketlerin üretiminde dijitalleşme uygulamaları başlamıştı. 1996 yılında tamamen entegre otomasyon adını verdikleri yöntem ile şirketler süreçlerinin bileşenlerini koordine edebilmiş ve yazılım ile donanımlarını bu süreçlere entegre etmişti. Siemens şirketi tarafından 2007 yılında geliştirilen PLM yazılımı ile ürün yaşam döngüsü yönetimi sağlanmıştır. PLM teknolojisi Mars'a gönderilen Curiosity adlı robotta da kullanılmıştır (Kahraman, 2016). 
İşletmelerin yönetiminde olacak değişikliklerin başında, fiziksel güçten ziyade zihinsel gücün daha ön plana çıkacağı öngörülmektedir. İş yapısının önceden planlanması için tasarım ve yaratıcılık öncelikli unsurlar olacaktır. İnsanın en önemli yaratacağı katma değerin, bu büyük veri sistemi içinde tasarlayıcısı olarak yer almasıyla ortaya çıkacaktır. Fizik gücüne dayalı faaliyetler ise akıllı makineler ve robotlar tarafından yerine getirilecektir. İşletmeye ait tüm işlemler sanal bir merkezden yönetilebilir. Geleceğin işletmelerinde işletme fonksiyonlarının tamamının elektronik ortamda sürdürülmesi hedeflenmektedir.

Tüm faaliyet kolları bilgi teknolojileri, dijital üretim süreçleri ve Nİ gibi yeniliklerden etkilenmektedir. Nİ sayesinde iş gücüne bağlı oluşan hataların yok olması hedeflenmektedir. Kendi kendini yöneten, öğrenen makineler ve hatalarını yine kendi içlerinde düzelten sistemler oluşturmak olanaklı hale gelmeye başlamıştır. Üretim bandında oluşacak bir hatayı önceden algılayan ve düzenleyen makineler kullanılmaktadır. İş gücü olarak programlanan makinelerin devreye alınması ve sistemin aksaklıklarını bulup analiz eden, onaran ve geliştiren sistemlerin uygulamasının başlamasıyla kaynaklar daha etkin ve verimli kullanılacaktır. Siemens şirketinin Almanya Amberg'de bulunan ve emek gücünün payının düşük olduğu dijital fabrikası bu yenilikçi teknolojileri günümüz itibarıyla en üst düzeyde kullanabilen sayılı fabrikalardan birisidir. 1989 yılında kurulan Amberg fabrikasında, üretim alanında değişiklik olmadan, üretim kapasitesi sekiz kat artmıştır. Bu fabrikada yapılan işlerin \%75'lik kısmı fiziki duran varlıklarla yürütülmekte ve kalan \%25'i emek gücüne dayanmaktadır. Malzemeler, hammadde deposundan otomatik olarak alınarak on beş dakika içerisinde makine bandına getirilmektedir. Üretim bandında insan eli sadece hammaddenin ilk yerleştirilmesi sırasında bir görev üstlenmektedir. Sonrasındaki tüm süreçler makinelerin kontrolünde seyretmektedir. Fabrikada üretilen bin adedin üzerinde mamul dünya üzerinde yaklaşık 60 bin müşteriye bir gün içerisinde gönderime hazır hale gelmektedir. Sevkiyat otomatik bir nakliye sistemiyle gerçekleşmektedir. Günde üç vardiya üzerinden tam gün faaliyet gösteren fabrikada mamul tamamlanma başarıs1 \%99,9988 (EP, 2015) olup diğer bir ifadeyle altı sigma düzeyine yaklaşmaktadır.

Yapay zekâya sahip üretim sistemleri ile mamuller üretim reçetelerini, üretimdeki tamamlanma oranlarını, plana uymak için izlemeleri gereken yolu bilecektir (Özhan, 2016). Akıllı üretim sistemleri, üretim hattında meydana gelen sorunlarda (örneğin, hammadde tedarikinde yaşanan gecikme, makine arızası vb.), en uygun alternatifi analiz ederek gerekli uyarıları gönderip üretimin en yüksek verimi sağlayacak şekilde devamı için çözüm üretip uygulamasını sağlayacaktır. Yapay zekâya sahip sistem, hammadde tedarikinde yaşanan gecikmenin süresini hesaplayarak, beklemenin mi yoksa başka bir malzemeyi üretim bandına almanın mı daha ekonomik olacağını hesaplayacaktır. Sistem aynı zamanda insanlarla da iletişimde olacağından, sistem tarafından alınan kararın uygulamasının kontrolü de istenirse insanların yetkisinde olacaktır.

Nİ sisteminin kullanıldı ̆̆ı alanlar arasında akıllı şehirler gelmektedir. Şehirlerdeki yol, bina, köprü ve diğer altyapı hizmetleri sensörler yardımı ile bütünleşmektedir. Bu fiziksel 
yapıların içlerine konan çipler ile yapıları ve üretildikleri malzemenin ölçümü uzaktan yapılarak faydalı ömürleri hakkında bir değerlendirme yapılmaktadır (Rifkin, 2015: 21). İş hayatının ve trafiğin yoğun olduğu büyük şehirlerde Nİ kullanımı değerli bir hale gelmektedir. Geleneksel şehirlerin akıllı şehirlere dönüşmesi ile trafik durumuna ve ulaşılmak istenen noktaya kalan tahmini süreye yönelik bilgilere ulaşılmaktadır. Trafikte ulaşılacak noktadaki otopark alanlarının doluluğu gibi farklı bilgilerin de kullanıcılara otomatik gelmesinin sağlanması mümkündür (Yüksek, 2015). Cep telefonlarına yüklü internet navigasyon sistemi günümüzde yoğun bir şekilde kullanılmaktadır.

NI'nin günümüzde yaygın olarak kullanıldığı bir diğer alan ise lojistik sektörüdür. Lojistik şirketlerinin operasyonlarının hızlı ve sağlıklı yürütülmesi için etkin bir iç denetim yapısına sahip olması gerekmektedir. Nİ'ye dayalı bilgi teknolojisinin iç denetim sistemine sağladığı yararlar geleneksel iç denetim sistemine göre üstünlük yaratmaktadır: Gerçek zamanlı verinin anlık olarak alınması, ülke genelindeki kablosuz ağlara bağlanılarak işlerin yapılması ve bulut bilişimin sunduğu entelektüel yönetim ile çok sayıda veri arasından ilgili taraflar etkileşim sağlamaktadır (Dai ve Ge, 2015: 55). Lojistik işletmeleri mal ve hizmet akışını izlemek için depolarında ve taşıtlarında sensörler ve izleme cihazlarından yararlanmaktadır. UPS kargo şirketi, internet veri ağı sisteminden yararlanmakta ve ABD'deki 60 bin aracını anlık olarak bu sistem yardımıyla izlemektedir (Muller, 2012).

Günümüzde Nİ ile bilgi toplayan ve öğrenen nesneler, iş dünyasında yavaş yavaş kullanım alanı bulmaktadır. Üç boyutlu yazıcılarla nesneler bir yerden başka bir yere taşınarak işyerlerinde üretim yapılmaktadır. Yazılım yardımıyla erimiş plastik, metal ve diğer malzemeler yazıcının içine gönderilmekte ve daha sonra yazıcı bu malzemeleri katmanlar halinde işleyerek fiziki ve biçimsel açıdan noksansız bir nesne üretmektedir. Bazı nesnelerin parçaları hareketli yapılmaktadır. Nesne tamamlandığında yazıcıdan çıkmaktadır. Yazıcıların sonsuz çeşitlilikte mamul üretecek şekilde programlanması olanaklı görünmektedir (Rifkin, 2015: 98). Üç boyutlu yazıcılarının her alanda kullanılmasıyla depolama maliyetleri de azalacaktır. General Electrics şirketinin biri Türkiye'de olan dünyadaki on fabrikasında verimliliği artıran ve stok maliyetlerini düşüren öğrenen ve konuşan makinelerle üretim yapılmaktadır. Geleneksel üretim yöntemine kıyasla üretim sürelerinde ve stok düzeyinde verimliliğin \%30 oranında artması planlanmaktadır (Çapa, 2016).

Nİ insanların kendi arasında yaptığı görüşmelere de katkı sağlayabilir. Toplantı sırasında akıllarda canlandırılan resimlere ait görseller sistem tarafından sunuda gösterilebilir. Günümüzde tıp alanında EEG teknolojisi ile sinir sistemi ve beyin dalgaları ölçülmektedir. Teknolojinin insan üzerinde giyilebilir bir şekle sokulması, yapay zekâ uygulamaları ve sanal gerçeklik simülasyonları ile beyin etkinliklerinin çözülmesi çalışmaları sürmektedir. Bu tür teknolojilerin gelişmesi ile bir kimsenin beyninde yaratılanın başkaları tarafından da izlenmesi mümkün olabilir. Akıllı telefonlar ile uzaktan ev eşyaları yönetilmektedir. Örneğin, evdeki kameralarla ortamın izlenmesi ve evin 1sısının ayarlanması bu akıllı telefonlarla 
yapılanlara birer örnektir. Akıllı telefonlar ile gelecekte çok daha fazla eşyanın yönetimi ve kontrolü sağlanacaktır.

Gelecekteki işletmeler, kendini yöneten ve kendi kendine öğrenen makinelerle donatılacaktır. Günümüzde öğrenen makinelere örnek olarak Google şirketindeki bilgisayar bilimcileri tarafından geliştirilen şifrenmiş bilgileri öğrenen ve bu şifreleri çözen sinir ağları verilebilir (Burges, 2016). İnsan ve kurumsal yönetime atıfta bulunarak ortaya çıkan öğrenen organizasyonlar gibi, makineler de bu öğrenme sürecinin parçası olacaktır. Kendi kendine park eden taşıtlar ve sürücüsüz taşıtlar günlük hayatta yer bulmaya başlamıştır. Sürücüsüz otobüsler kullanılmaktadır. Dolayısıyla, kendi kendini yöneten işletmeler de bu gelişim sürecinin bir parçası olmaya adaydır.

Akıllı fabrikalarda bir diğer uygulama da dijital ikiz yaratılmasıdır. Dijital ikiz, dijital ortamda var olan ve gerçeğiyle aynı olan bir benlik oluşturmak anlamına gelmektedir. Dijital ikiz teknolojisinin ana fikri, lokomotiflerden jet motorlarına tüm makinelerin birer dijital modelini yaratmaktır. Böylece, makinelerin tüm çalışmaları dijital ortamda simülasyon yapılmakta, yanlış gidebilecek durumlar önceden saptanmakta ya da çalışma ortamındaki herhangi bir aksaklık henüz gerçekleşmeden makinelerin çalş̧ması düzenlenmektedir. Örneğin, rüzgâr türbinleri, gemiler ya da enerji santrallerinin çalışmaları bir bilgisayar yardımıyla simülasyon yapılmakta ve bu sayede üretim başlamadan en iyi çalışacak tasarımları öğrenmektedir (GE, 2015).

Yakın gelecekte küresel bir nöre-ağ kurulması sonucu; herkes ve her şey birbirine bağlanacaktır. Günümüzde kullanılmakta olan bulut teknolojisi (Singh vd., 2016) bu sürecin adımları arasında sayılabilir. Küreselleşme ile gizliliklerin azalması hızlanmış ve bu küresel nöro-ağ ile insanlık mahremiyeti daha da azalarak şeffaflık çağına doğru yönelim başlamıştır. Nİ’nin şirketlerin ve insanların günlük yaşamlarının bir parçası olmasıyla verilerin güvenliği konusu öne çıkmaktadır. Veri güvenliği bireyler ve şirketler için farklı anlam taşıyabilmektedir. İstekli olarak paylaşılan bilgiden dolayı kişi ve şirketlere maddi zarar gelmemesi ve itibar kaybı yaşanmaması öncelikli konudur. Sistemler birbirine kişi ve şirketlerin kontrolü dışında bağlanmaktadır. Dolayısıyla bir sistemde paylaşılan bilgi, başka bir sistemde görünür duruma gelmektedir. Akıllı işletmeler, akıllı şehirler, akıllı ülkeler, akıllı dünya yaratılmaya çalış1ırken, paylaşılan bilginin güvenliği ve denetimi konusu sorunsaldır. $\mathrm{Bu}$ konudaki yasal altyapının oluşturulması amacıyla Avrupa komisyonu 2012 yılında çalışmalara başlayarak güvenlik önlemlerinin hayata geçirilmesi için çeşitli mekanizmalar oluşturulmasını önermiştir (Rifkin, 2015: 85). Bu önerilerden biri, kişisel verilerin yetkisiz kullanımını önlemek ve veriyi kullananların kimlik bilgilerinin kişisel veri sahiplerine iletmektir. Türkiye'de de gerçek ve tüzel kişilere ait verilerin gizliliği 6698 sayılı Kişisel Verilerin Korunması Kanunu ile güvence altına alınmıştır (TBMM, 2016). 


\section{NESNELERİN İNTERNETINE DAYALI DENETIM YAKLAŞIMI}

Denetim, şirketlerin gerçekleştirdikleri ekonomik faaliyetler ve olaylara ilişkin iddialarla, genel kabul görmüş ölçütler arasındaki uygunluğun derecesini araştırmak ve sonuçlarını ilgili kullanıcılara iletmek amacıyla nesnel biçimde kanıt toplama ve değerlendirme süreci olarak tanımlanmaktadır (AICPA). Şirketler faaliyetlerini şirket içinde kurdukları iç denetim ile izlemekte ve ayrıca denetim alanında uzman olan bağımsız denetçilerden (Selimoğlu vd., 2015) hizmet alarak da finansal tabloların denetimini yaptırmaktadır. NI'ye bağlı gelişmeler işletmeleri, muhasebe sistemini ve denetimi etkilemektedir. İnternetin üretimde kullanılması, iş geliştirmeden mühendislik alanına birçok yenilik getirmektedir. Üretim yapan şirketlerde makine, tesis, cihaz ve demirbaş gibi duran varlıkların internet ağına bağlanarak insanlarla ve diğer nesnelerle iletişim kurmaları sağlanmaktadır. Üretimde kullanılan aktiflerin birbirleri ile gerçek zamanlı iletişim kurarak daha etkin çalışmaları sağlanacaktır. Bir ürünün araştırma aşamasında, sistem ileride çıkacak zorluklara ve maliyete yönelik geri bildirim verecektir. Böylelikle, araştırılan ürünün mevcut aktiflerle yapılmasının zorluğu veya yeni yatırımın maliyeti hakkında elde edilecek bilgi ile süreç daha fazla ilerlemeden sonlandırılabilecektir. Birbirine bağlı nesneler ve Nİden alınan sürekli geri bildirimler sayesinde hata riski azalacak ve kaynaklar etkin kullanılacaktır. Bilgiye ulaşımın hızlanması ve bilginin görünür olması sayesinde şirketteki süreçler şeffaflaşacaktır. Tüm sistemin birbirine bağlı olması, üretim aşamasında aksama olmamasını, ürünlerin kalite kontrolünün yapılarak olası hataların gerçekleşmeden saptanmasını sağlayacaktır. Nİ sayesinde kolaylaşacak veri madenciliği veya büyük veri analizi yöntemleri ile fabrikalarda üretimin verimi artacaktır.

Akıllı gezegene, akıllı şehirlere, akıllı fabrikalara doğru yol alırken işletmelerde muhasebe girişleri, stok sayımları da akıllı ve öğrenen sistemlerle kolayca yapılabilecektir. Akıllı fabrikalarda stok denetimi için öncelikle iyi bir yazılım mühendisliği gerekmektedir. $\mathrm{Bu}$ yazılımlar sonucu siparişin alınmasıyla birlikte gerekli olan malzeme depodan sorgulanır ve eğer depoda yeterli malzeme yoksa bunlarla ilgili sipariş akıllı makineler tarafından tedarikçilerden temin etmesi istenir. İşletmenin bilgi işleme sistemine girilen bu bilgiler daha sonra şehrin ve ülkenin genel veri ağına işlenerek denetime hazır hale gelecektir. Öğrenen ve hayatın içinde daha çok yer alan nesneler, her alanda olduğu gibi, muhasebe sistemi ve denetim üzerinde de etkili olacaktır.

Gelecekte Nİ yardımıyla; işletmelerdeki depo sayım ve kontroller insansız hava araçları (dron) ile yapılabilir. İnsansız hava araçları ile fabrikalarda gereksinim duyulan hareket becerisi artacaktır. İnsansız hava araçlarına monte edilecek kameralar ile deponun durumunun izlenerek gereksinim oldukça raporlama yapması sağlanabilir. Bunların bazıları gelecekte kızıl ötesi sensörlerle donatılabilir. Fabrikalardaki üretim süreçlerinde otomasyon arttıkça robotlar da artmaktadır. Bir sonraki gelişim sürecinde beklenen ise, üretim bantlarındaki robotların kendilerinin karar vermesi ve insan müdahalesine gerek duymadan özerk bir şekilde davranmasıdır. Fabrikada kullanılacak Nİ teknolojisiyle stok kontrolleri, 
stok sayımları, stok siparişi, ortaya çıkan hataların çözümü, makine bakımlarının izlenmesi ve faaliyetlerin denetimi dahil birçok süreçte yarar sağlanacaktır.

Geleceğin işletmelerinde ürünü raftan alarak kasaya taşımak yerine, sadece raflara dokunarak kasada hazır olmasını sağlayan bağlantılı raflar kullanılmaya başlanacaktır. Reklamlarda görülen bir malın cep telefonu kullanarak satın alınması ile zamandan tasarruf ederek alışveriş hızlanacaktır. Alışveriş ve ödeme şekilleri değişime uğramaktadır. Nakit ödemesiz ve kasiyersiz yazar kasalar işletmelerde kullanılmaktadır. Hayatın ayrılmaz bir parçası olan kredi kartları ile nakit para kullanımı giderek azalmaktadır. Hükümetler de paranın izinin daha kolay izlenmesi ve kayıt dışılığı önlemek için elektronik uygulamalara ağırlık vermektedir. Müşteri ödeme noktasına geldiğinde, yaptığı alışverişe ait ürünler sensörler yardımıyla tanınarak ödeme yapılan tutarın bankadaki hesabından düşülmesi ve faturasının e-posta adresine gönderilmesi olanaklıdır.

Geleneksel denetim yaklaşımında, denetim firması denetlenecek firmaya yaptı̆̆ müşteri ziyaretleri sonrasında denetim sözleşmesi imzalanmaktadır. Denetim şirketi, denetim planlaması yaparak, ara denetim, dönem sonu denetimi, stok sayımı ve denetim raporunun hazırlanması şeklinde denetim sürecini bölerek planlama yapmaktadır. Ara denetim, dönem sonu denetimi ve stok sayımı için denetçiler fiziksel olarak denetlenen şirkete giderek çalışmaktadır. Denetim raporu genellikle denetim şirketinde hazırlanmakta ve nihai raporu imzalamadan önce denetlenen şirkete gidilerek karşılıklı olarak elde edilen sonuçlar son bir kez değerlendirilmektedir. Bu süreçte, son anda ortaya çıkan ertelemeler nedeniyle planlama süreci olumsuz etkilenmekte, şirkete gidilip dönülmesinde ek giderlere katlanılmakta ve ayrıca seyahat nedeniyle para ile iş gücü kaybı olmaktadır.

Nİ ortamında denetim yaklaşımının geleneksel denetim yaklaşımına üstünlükleri bulunmaktadır. Nİ'ne dayalı denetim yaklaşımında denetçi her zaman işletmedeki faaliyetler hakkında bilgi sahibi olmaktadır. Böylece denetçinin faaliyetler tamamlandıktan çok sonra değil, faaliyetler devam ederken haberdar olma ve yönetimi uyarma firsatı olacaktır. Bu nedenle, işletme faaliyetleri ve denetim faaliyetlerinin birlikte veri ağında uyum sağlaması gerekmektedir. Nİ'nin kullanıldığı denetim yaklaşım tasarımı Şekil 1'de sunulmaktadır.

Denetimin yeni boyutunda işletmelerden gelen her türlü veri denetlenmemiş veri toplama merkezine yüklenecektir. Şekil 1'de sunulduğu üzere, işletmelerden gelen merkezdeki denetlenmemiş veri, örümcek ağı gibi oluşturulmuş fiber optik ağlar yardımıyla ana merkezde toplanmaktadır. Denetlenmemiş bilgi işletme tarafından denetim sözleşmesi imzalanan denetçi tarafından denetlenecek ve denetlenmiş veri bankasına yüklenecektir. Kayıtlar üzerinde inceleme yapan denetçi, kayda ait ilgili belgelere de sistem üzerinden ulaşacaktır. Elektronik ortamda üretilen belgeler ilgili kayıtlarla kendiliğinden ilişkili olurken, manüel olarak üretilen belgeler de taranarak sisteme yüklenecektir. Finansal tabloların denetimi işletmenin sisteme yüklediği ana veri merkezinden elde edilen bilgilerle denetlenecektir. Finansal tabloların tamamlayıcısı ve ayrılmaz bir parçası olarak kabul edilen dipnotlar da Nİ sisteminde kendiliğinden türetilecektir. 


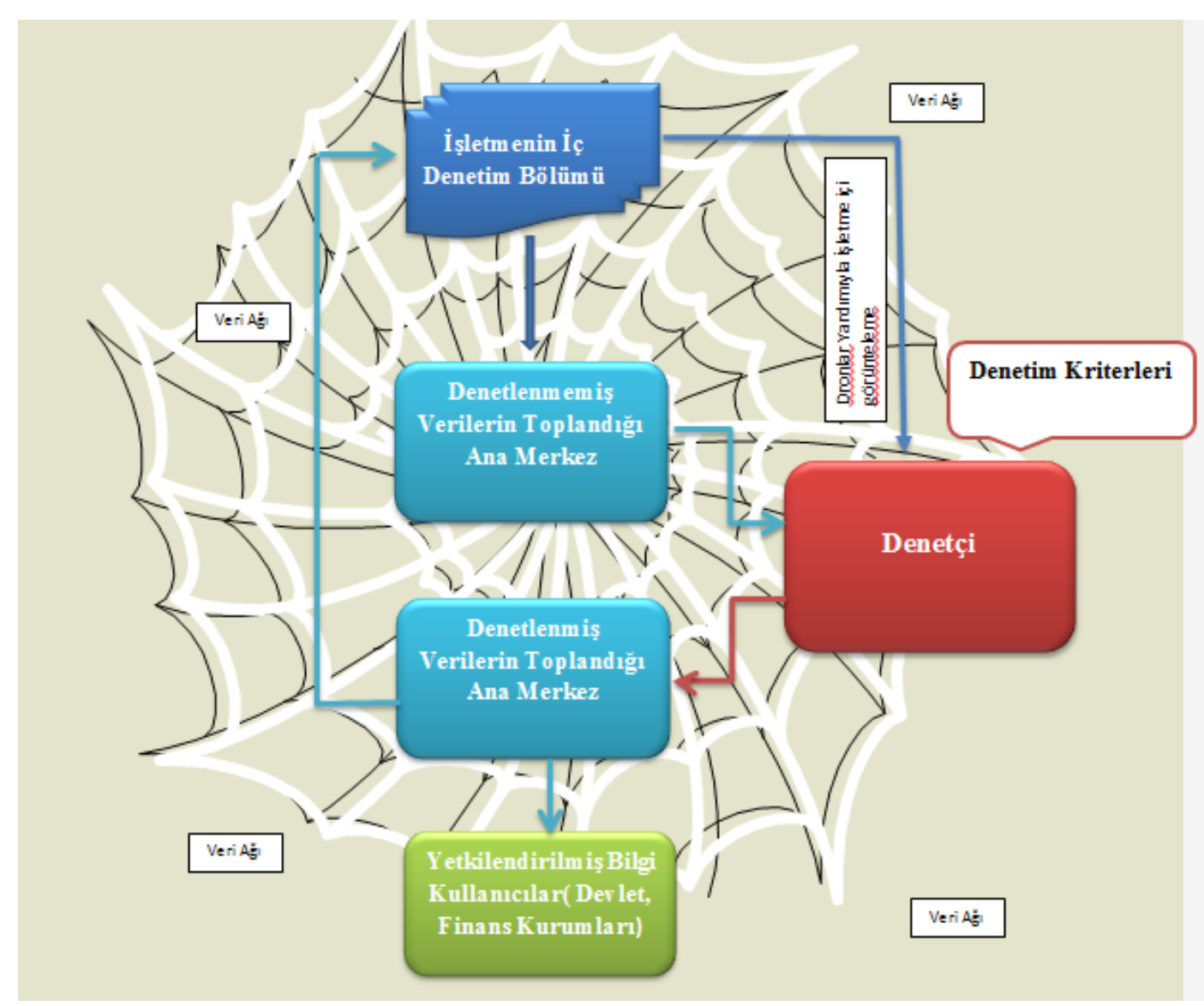

Şekil 1. Nesnelerin İnternetinde Denetim Yaklaşımı

Dijital dünyada denetçinin bilgiye sınırsız ve anlık ulaştığı bir ortamda, denetim faaliyeti denetlenen şirkete fiziksel olarak gidilmeden yapılacaktır. Nİ sistemi üzerinden denetçi denetlenecek işletme yetkilileriyle görüşüp denetim anlaşmasını imzalayacaktır. İmzalama süreci gerekirse telekonferansla yapılacak ve sözleşme elektronik olarak imzalanacaktır. Sözleşmenin veri ağında imzalanmasıyla denetçi, denetlenecek işletmenin elektronik ortamdaki bütün bilgi ve belgelerine veri merkezi üzerinden ulaşma olanağına erişecektir. Görsel olarak işletmeyi denetlemek isteyen denetçi, ekranlar, insansız hava araçları ve robotlar yardımıyla işletmenin içinde internet üzerinden denetim yapacaktır. İşletmenin stoklarını, depolarını, üretim hattını, satış ve sevkiyat sürecini görsel olarak istediği anda, işletmeye haber vermeden kontrol edecektir. Şirket içinde bulunan güvenlik vb. kameralara da erişim sağlayarak tesadüfi anlarda denetim yapması mümkün olacaktır. Günümüzde kullanılan facetime gibi uygulamalar ile çalışanlarla iletişim kurarak gerekirse onlara soru soracaktır. Örneğin, işletmede çalışan personelin işe alımı, fiziksel mevcudiyeti, fazla mesai ödemesine hak edişi gibi konular araştırılırken, işçinin sistemde kayıtlı göz taraması, parmak izi ve yüz tanıma bilgileri ile gerekli denetim çalışması yapılacaktır. 
Günümüzde çok uluslu şirketler toplantılarını telekonferans ile yapmaktadır. Farklı coğrafi bölgelerdeki hukuk davalarında internet üzerinden sorgulama yöntemi kullanılmaktadır. Google sokak görünümü gibi uygulamalar ile yer saptaması yapılmaktadır. $\mathrm{Bu}$ teknolojik gelişmeler her alanda olduğu gibi denetim alanında da kolaylıklar sağlayacak ve denetimi geleneksel boyutunun dişında yeniden tasarlanmasına neden olacaktır. Nİ şirketlere maliyet firsatı sunacaktır. Seyahat, ulaşım ve konaklama giderleri ortadan kalkacağından denetim ücretine eklenen bu tür yan giderler ve zaman kayıpları olmayacaktır.

Nİ ile tüm sistemler birbirine entegre olduğunda muhasebe denetimi için yer ve zaman önemli olmayacaktır. Şekil 1'deki gibi, veriler küresel bazda örümcek ağ gibi bir sistemle (fiber optik kablolarla) birbirine bağlanacak ve yetkisi dahilinde olan kişiler bu bilgilere ulaşacaktır. Bu durumda denetçi anlaşma imzaladığı işletmenin ana veri merkezinde toplanan bilgilerine ulaşmasını sağlayan bir koda sahip olacaktır. Bu kod yardımıyla işletmenin bütün kayıtlarına ulaşma olanağına sahip olacaktır. Bu kod yardımıyla maddi doğrulama ve uygunluk denetimi yapabilecek, görüntülü olarak personelle bilgi alışverişi yapabilecek ve istediği anda işletme içinde sanal tur yapıp insansız hava araçları yardımıyla stok kontrolleri yapma olanağına sahip olacaktır. Dev bir ekran yardımıyla işletmenin içinde gibi çalışacaktır.

Kendini yenileyen ve öğrenen nesneler insanın iş yükünü ve hata yapma riskini önemli ölçüde azaltacaktır. İnsanlar, yeniliğe, yaratıcılığa, tasarıma, araştırma ve geliştirmeye daha çok zaman ayıracaktır. Kişiye bağlı öznel karar vermeden doğan hata ve hilenin de önüne geçilmesine olanak sağlanacaktır.

\section{STOK DÖNGÜSÜNÜN DENETIMI}

Üretim yapan şirket bilançolarının aktif tarafında önemli bir paya sahip olan hesap kalemlerinin başında ticari alacaklar, stoklar ve maddi duran varlıklar bulunmaktadır. Maddi duran varlıkların üretim amacıyla kullanıldıkları ve üretilen mamullerin de satılınca ticari alacağa dönüştüğü gerçeğinden hareketle, stokların yönetimi ve denetimi şirket başarısında büyük önem taşımaktadır. Şirketler satışlarını gerçekleştirmek için istenen nitelikte ve miktarda stoklara sahip olmalıdır. Stoklar, işletmenin normal faaliyet dönemi içinde üretimde kullanmak üzere satın aldığı ilk madde ve malzemeler, üretim aşamasında bulunan yarı mamuller ve ürettiği mamuller ile satışa hazır ticari malları içermektedir. Kaliteli stoklara sahip olmak ve hızlı bir şekilde stokları döndürmek şirket kârlılığını ve verimini olumlu etkilemektedir.

Stokların denetiminin amac1, muhasebe ilkelerine uygun olarak muhasebeye kayit edildiğinin ve finansal tablolarda doğru bir şekilde raporlanmış olduğunun saptanmasıdır. $\mathrm{Bu}$ amaca ulaşmak için denetçi stokların fiziksel varlığını, işletmenin sahipliğinde bulunduklarını, maliyet değerlerinin üzerinde bir değere satılabilir durumda olduklarını saptamalıdır. Denetçi aynı zamanda teknolojinin değişmesi nedeniyle değer kaybına uğrayan, bozulan, modası geçen ve yıpranan stoklar için yeterli düzeyde ve gerçekçi karşılık ayrıldığını araştırmalıdır. 
Stokların, işletmenin varlık yapısı içerisinde çoğu zaman en önemli ve en büyük hesap olması; fiziki sayım ve gözlemin zaman alıcı ve maliyetli olması; çeşitliliği nedeniyle zor ve riskli oluşu; tanınmaları ve değerlemesindeki güçlükler; hata ve hile risk düzeyinin yüksek olmas1 unsurları, stokların denetimini önemli yapmaktadır (Bozkurt, 2006: 307-308). Stoklarda oluşacak hata ve hileler hem bilançonun hem de gelir tablosunun doğru ve dürüst bir şekilde sunulmamasına neden olmaktadır. Karmaşık bir üretim sürecine sahip veya çok sayıda mamul üreten şirketlerde, maliyetlerin hesaplanmasında hatalar olabilmektedir. Bu hatalar, dönem sonu stoklar tutarının bilançoda hatalı gösterimine; aynı zamanda döneme ait satışların maliyet tutarının da yanlış belirlenerek brüt kârlılı̆ıın hatalı sunulmasına yol açmaktadır.

Stoklar hesap grubunun denetimindeki hedefler arasında, stok giriş ve çıkışlarının gerçekliğini anlamak; stokların maliyet bedellerine uygun olarak kayıtlara alındığını belirlemek; cari dönemde kullanılan stok maliyetlerinin ilgili hesaba ait maliyete yansıtıldığını saptamak; işletmenin sahip olduğu tüm stokların envantere dahil edildiğini test etmek; envanterde yer alan stokların değerleme ilkelerine uygun hesaplandığını ölçmek sayllmaktadır (Kaval, 2008: 248).

Denetçi, denetlenen şirketin iddialarına finansal tablolar düzeyinde bir bütün olarak ve hesap bazında kontrol testleri ve maddilik testleri yaparak karşılık vermektedir. Maddilik testleri detay testler ve analitik maddi doğrulama testleri olarak ikiye ayrılmaktadır. Denetim kanıtı elde edilirken tetkik (fiziki inceleme), gözlem, dış teyit (doğrulama), yeniden hesaplama, yeniden uygulama, sorgulama ve analitik prosedürler yöntemlerinden yararlanılmaktadır (KGK, BDS 500). Analitik prosedürler, finansal tablolar ve hesap grupları üzerinde denetlenen şirket yetkilileri ile yapılan görüşmeler sonucunda elde edilen finansal ve finansal olmayan bulgular arasındaki ilişkilerin mantıksal olarak analiz edilmesiyle yapılan denetimdir (KGK, BDS 520). Belirli bir hesabın denetiminde tek bir yöntem uygulanabileceği gibi, farklı yöntemler birlikte de uygulanabilir. Denetim kanıtı toplanmasında, şirketin stok fiili sayım yönetmeliğinin incelenmesi, müssteri tarafından yapılan fiili stok sayımına katılarak süreç hakkında gözlemde bulunulması, fiili sayım sonrası elde edilen çıktılar ile kayıtlarda gözüken miktar arasında olabilecek farklara ait açıklama alınması, hatalı kayıtların düzeltilmesi ve stoklara ait dönem sonu değerlemesi bulunmaktadır (Güredin, 2000).

Stoklara ait denetim kanıtı elde edilmesinde denetçi tarafindan sıklıkla kullanılan denetim prosedürleri tetkik (kayıt, belge ve varlıkların fiziki olarak incelenmesi) ve gözlemdir (başkaları tarafından uygulanan bir süreç veya prosedürün izlenmesi). İşletmelerde stok sayımları genellikle dönem sonlarında yapılmaktadır. Denetim şirketi tarafindan tüm müşterilerinin çoğunlukla 31 Aralık olan dönem sonlarındaki stok sayımlarının tamamına katılmak için yeterli sayıda denetçi görevlendirilememektedir. Stok sayımları zaman alan ve maliyetli bir süreç olduğundan denetçinin \%100 fiziki inceleme yöntemi kullanılması orta ve büyük işletmelerde olanaklı değildir. Denetçi, müşteri işletmenin stok sayım sonucunun güvenilirliğinden emin olmak için işletmenin stok sayım yönergesi olup olmadığını, varsa 
yeterliliğini, iç kontrolün stoklar üzerindeki etkinliğini de araştırarak bir görüş elde etmeye çalışmaktadır. Nİ'nin uygulanmaya başlamasıyla bu zorlu süreç kolaylaşarak zaman ve maliyet tasarrufu sağlayacaktır.

NI'nin kullanıldığı bir denetim yaklaşımında stok döngüsünün maddi (fiziki) doğrulaması şu şekilde yapılabilir. Müşteri işletmenin stok sayım planı elektronik ortamda denetçi tarafından gözden geçirilir. Denetçi kendi şirketinden müşteri işletmenin stok sayım işlemine kameralar, robotlar yardımıyla gözlemci olarak katılır. Stokların depoya girişi sırasında giriş kayıtlarının yapıldığı ve stokların depodaki akıllı raflara yerleştirildiği kayıtlar üzerinden ve görsel olarak denetlenir. Depoda bulunan stoklara ait raf bilgilerine sisteme girilerek ulaşılır. Stoklarda oluşacak bozulmanın tespiti ürün barkodunun ya da akıllı rafların renk değiştirmesiyle ve sisteme uyarı mesajı göndermesiyle sağlanır. Denetçi ilgili stok ve ürünü görmek istediğinde üç boyutlu yazıcılar aracılıyla ofisinde inceler.

Depodaki stokların maliyeti ağırlık sensörleri yardımıyla anlık olarak belirlenir. $\mathrm{Bu}$ ağırlık sensörleri ayrıca yeni siparişin sistem tarafından kendiliğinden verilmesini de sağlayacaktır. Sensörler sadece elektronik sensörler olmayıp kimyasal veya biyolojik sensörler de olabilir. Sensör teknolojisinin yaygınlaşmasıyla daha kapsamlı çözümler geliştirilebilir. Nİ ağında bilgiler analiz edilir ve nesnelerin kendi çevrelerini anlayıp, diğer nesnelerle iletişime geçerek karar vermesi sağlanır (Baysan, 2016).

Tablo 1. Stoklar Döngüsü Denetim Yaklaşımları

\begin{tabular}{|c|c|c|}
\hline Denetim İlkesi & Geleneksek Yaklaşım & Nesnelerin İnterneti Yaklaşımı \\
\hline $\begin{array}{l}\text { Tamlık } \\
\text { (ör. Stok alış } \\
\text { faturasının } \\
\text { kontrolü) }\end{array}$ & $\begin{array}{l}\text { Denetçi, denetlenen şirkete } \\
\text { stoklar hesabının muavinini alır ve } \\
\text { buradan seçtiği alış faturalarını mahsup } \\
\text { fişleri arasından bularak fiziki olarak } \\
\text { inceler. Faturanın BA formunda beyan } \\
\text { edildiğini görmek için şirket yetkilisinden } \\
\text { beyannameyi talep eder. Satıcı ile } \\
\text { doğrulama yapar }\end{array}$ & $\begin{array}{l}\text { Denetçi, ağ üzerinden muavini inceler ve } \\
\text { seçtiği alış faturası tıkladığında taranmış } \\
\text { faturayı sistemden görür. Faturanın BA } \\
\text { formunda olduğunu } \text { ve faturayı } \\
\text { düzenleyen firmanın da BS formunda } \\
\text { beyan ettiğini sistem üzerinden denetler. }\end{array}$ \\
\hline $\begin{array}{l}\text { Tamlık } \\
\text { (ör. Alış } \\
\text { faturasına ait } \\
\text { stoğun fiziki } \\
\text { teslim alımı) }\end{array}$ & $\begin{array}{l}\text { Denetçi, stok alışlarına ait fiziki teslimi } \\
\text { geriye dönük olarak yapması oldukça } \\
\text { zordur. Ancak, denetime gittiğinde mal } \\
\text { kabul deposuna giderek o anda gelen } \\
\text { malları tetkik edebilir. }\end{array}$ & $\begin{array}{l}\text { Denetçi, stok alışlarına ait tetkiki, } \\
\text { denetlenen müşterinin haberi olmadan, Ni } \\
\text { üzerinden kamera ve dronlar ile görebilir. } \\
\text { Fiziki girişleri daha sonra faturalar ile } \\
\text { eşleştirip denetimi yapar. }\end{array}$ \\
\hline $\begin{array}{l}\text { Var Olma } \\
\text { (ör. Fiili stok } \\
\text { sayımı) }\end{array}$ & $\begin{array}{l}\text { Müşteri işletmenin stok sayımına katılarak } \\
\text { gözlemde bulunur. Sondajlama usulü } \\
\text { tetkik yapabilir. }\end{array}$ & $\begin{array}{l}\text { Üzerindeki ağırlığı ölçen akıllı raflar ve } \\
\text { ürünlerin barkodunu okuyan kızıl ötesi } \\
\text { 1şınlar ile anlık stok miktarı saptanır. } \\
\text { Gerektiğinde kamera ve dronlar ile fiziki } \\
\text { tespit yapılır. }\end{array}$ \\
\hline $\begin{array}{l}\text { Doğruluk } \\
\text { (ör. } \\
\text { Dönemsellik) }\end{array}$ & $\begin{array}{l}\text { Dönem sonu tarihinden önceki ve bir } \\
\text { sonraki faaliyet döneminin ilk irsaliyeleri } \\
\text { ile fatura tarihleri aynı dönemde oldukları } \\
\text { belgeler üzerinden incelenir. }\end{array}$ & $\begin{array}{l}\text { Fatura ve ilgili irsaliyenin aynı faaliyet } \\
\text { dönemine ait olduğu sistem üzerinden } \\
\text { denetlenir. }\end{array}$ \\
\hline $\begin{array}{c}\text { Doğruluk } \\
\text { (ör. Değerleme) }\end{array}$ & $\begin{array}{l}\text { Fiili stok sayım listesi ile kayıtlarda } \\
\text { gözüken miktarlar kullanılan muhasebe }\end{array}$ & $\begin{array}{l}\text { Akıllı raflar, ağırlık sensörleri ve kızıl } \\
\text { ötesi 1şınlar sayesinde fiili miktarlar ile }\end{array}$ \\
\hline
\end{tabular}




\begin{tabular}{|c|c|c|}
\hline & $\begin{array}{l}\text { programı veya excel vb. programlar } \\
\text { yardımıyla incelenir. Farkların muhasebe } \\
\text { sisteminde düzeltildiğini araştırır. Denetçi } \\
\text { belgeler üzerinde çalışır. }\end{array}$ & $\begin{array}{llr}\text { kayıtlar arasında } & \text { oluşan farklar anlık } \\
\text { saptandığından, şirket personeli bu } \\
\text { farkları her } & \text { zaman araştırarak } \\
\text { düzeltmektedir. } & \text { Fiili miktarlar ile } \\
\text { kayıtlardaki } & \text { miktarlar } & \text { sürekli } \\
\text { örtüşmektedir. } & & \end{array}$ \\
\hline $\begin{array}{l}\text { Doğruluk } \\
\text { (ör. Stok değer } \\
\text { düşüklüğ̈̈ } \\
\text { karş1lığ1) }\end{array}$ & 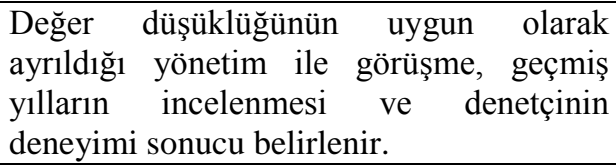 & $\begin{array}{l}\text { Bir sonraki dönemde, stokların maliyet } \\
\text { değerinin altında satılıp satılmadığı sistem } \\
\text { üzerinden brüt satış zararı raporu alınarak } \\
\text { belirlenir. }\end{array}$ \\
\hline $\begin{array}{l}\text { Yasallık } \\
\text { (ör. Kanunlara } \\
\text { uyum) }\end{array}$ & $\begin{array}{l}\text { Denetçi, muhasebe, vergi ve denetim alanı } \\
\text { ile şirketin içinde bulunduğu sektöre ait } \\
\text { mevzuatı okuyup takip etmelidir. }\end{array}$ & $\begin{array}{l}\text { Şirketi ilgilendiren konulardaki mevzuat } \\
\text { bilgisi ve meydana gelen değişiklikler NI } \\
\text { üzerinden denetçiye uyarı olarak gelir. }\end{array}$ \\
\hline $\begin{array}{c}\text { Yasallık } \\
\text { (ör. İstenilen } \\
\text { standartlara göre } \\
\text { raporlamanın } \\
\text { hazırlanması) }\end{array}$ & $\begin{array}{l}\text { VUK, UFRS, SPK vb. istenen mevzuata } \\
\text { göre finansal raporlamanın yapıldığ } 1 \\
\text { denetlenen şirketin mizanı ile temel } \\
\text { finansal tabloları manüel olarak denetlenir. }\end{array}$ & $\begin{array}{l}\text { Mizandaki bakiyeler ve finansal tablolar } \\
\text { arasındaki uyum kendiliğinden denetlenir. } \\
\text { Fark olması durumunda sistem uyarır. }\end{array}$ \\
\hline $\begin{array}{l}\text { Sınıflandırma } \\
\text { ve } \\
\text { Anlaşılabilirlik } \\
\text { (ör. İç kontrol } \\
\text { sistemi) } \\
\end{array}$ & $\begin{array}{l}\text { Denetçi, yönetim ile yaptığ soruşturma ve } \\
\text { gözlem vb. denetim yöntemleriyle iç } \\
\text { kontrol sisteminin etkinliğini değerlendirir. }\end{array}$ & $\begin{array}{l}\text { Akıllı işletmeler ve öğrenen sistemler } \\
\text { sayesinde iç kontrol sistemi etkin bir } \\
\text { şekilde çalışır ve oluşacak hatalar akıllı } \\
\text { sistemlerin dijital ikizleri aracıyla önceden } \\
\text { belirlenip önlem alınır. }\end{array}$ \\
\hline $\begin{array}{l}\text { Sinıflandırma } \\
\text { ve } \\
\text { Anlaşılabilirlik } \\
\text { (ör. Finansal } \\
\text { tablolara ait } \\
\text { dipnotlar) } \\
\end{array}$ & $\begin{array}{l}\text { Denetçi kendisine sunulan dipnotları ilgili } \\
\text { hesapların ayrıntısından ve belgelerden } \\
\text { manüel olarak denetler. }\end{array}$ & $\begin{array}{l}\text { Dipnotlar NI sistemi üzerinden hazırlanır. } \\
\text { Veriler ilgili belgeler tarafından } \\
\text { desteklenmektedir. }\end{array}$ \\
\hline
\end{tabular}

Stoklara ait denetim testleri yapılırken, tamlık (bütün işlemlerin kayıtlara aktarılması), var olma (işlemlerin ilgili dönemde gerçekten gerçekleşmesi), doğruluk (hesaplama ve değerlemenin doğruluğu), yasallık (kanun ve mevzuata uygunluğu) ve "sinıflandirma ve anlaşılabilirlik" (finansal bilgilerin uygun olarak sunulması ve tüm önemli işlemlerin raporda açıklanması) ilkeleri test edilmektedir (KGK, BDS 315). Bu ilkeler ve ilgili örnek denetim çalışması Tablo 1'de ilk sütunda verilmektedir. Tablo 1'deki ikinci ve üçüncü sütunlarda stoklar denetiminde geleneksel yaklaşım ve Nİ yaklaşımı karşılaştırmalı olarak sunulmaktadir.

\section{SONUÇ}

İnsan zekâsının sınırlarını tahmin etmek zordur. İnsan zekâsının ürünü olan bilgisayarlar bilgi depolama işlevinin ötesine geçerek, insan zekâsıyla yarışmaya başlamıştır. En eski oyun olarak kabul edilen Go oyunu için geliştirilen yazılım, dünyanın en iyi ikinci oyuncusunu dörde bir gibi açık bir skorla yenmiştir. Geliştirilen bu tür yazılım programları ve internete yapılan bilgi girişleri günümüzde insan kaynaklıdır. Ancak, insanın bilgisinde, zamanında ve veri girişinin doğruluğunda zayıflıklar vardır. İnternete veri girişindeki bu kısıtlamaların aşılması amacıyla, internet çevresindeki nesnelerden de veri toplamalı ve bu 
verileri yorumlayarak otonom halde yönetebilmelidir. Bu fikirden yola çıkarak Nİ kavramı ortaya çıkmıştır.

Nİ sensörler, aktüatörler, veri tabanları, ağlar, yazılım ve diğer makinelerden oluşmaktadır. Nİ düşünen ve öğrenen organizmalardır. Nesneler, kendileri dışındaki diğer nesneleri fark ederler ve onlardan bilgi toplayarak iletişime geçerler. NI'ler bağımlı, yarı bağımlı veya tamamen bağımsız olarak hareket edebilirler. Nİ ile şirketlerin gelecekte iş süreçleri etkilenecektir. Bu süreç, dördüncü sanayi devrimine gidilen yolda endüstri 4.0 denen gelişmelerle bazı üretim tesislerinde uygulanmaya başlamıştır. Bu süreç verimliliği getirmekte olup rekabet üstünlüğü sunmaktadır. Bu çalışmada, şirketlerin faaliyetlerinde önemli bir yer tutan stoklar hesabının yönetiminde ve denetiminde yaşanacak gelişmeler incelenmiştir.

Stok kalemleri ak1llı internet sistemleri ile kendi kendilerini yöneten nesneler olacaktır. Stoklar üretim süresince gerekli kontrolleri yaparak, insan hatası olmadan, zamanı en verimli kullanarak rekabet üstünlüğü sunacaktır. Bu süreç, tedarik aşamasından son tüketiciyi bilgilendirmeye kadar süren bir süreçtir. Üretim için ihtiyaç olan stok kaleminden, üretim hattının izlenmesi, satışa sunulması, müşteriye internet ortamında bilgi verilmesine kadar devam etmektedir. Şirketteki muhasebe kayıtları da bu süreç içerisinde entegre edilecektir. Böyle bir sistemin uygulanması ve aynı zamanda da iç ve dış denetime olan yansımaları bu çalışmada incelenmiştir. Bu bütünleşik sistemin denetimi, geleneksel denetim yöntemleri üzerinde farklılaşmaya neden olacaktır.

Teknolojinin öğrenebilen ve kendi kendini yönetebilen dijital bir aşamaya geldiği bir ortamda stokların yönetimi ve denetimi kolaylaşacaktır. Akıllı raflar, ağırlık sensörleri, kimyasal sensörler, biyolojik sensörler, sanal kişisel asistanlar, dev ekranlar, ortak veri ağ1 kullanımının yaygınlaşmasıyla stokların denetimi daha hızlı, kaliteli ve düşük maliyetli olacaktır. Akıllı ve öğrenen makinelerin dijital ikizleri sayesinde bozulma, çalınma, kötüye kullanma gibi durumlarda sistem yöneticisine bilgi verilecek ve varlıkların korunmasındaki etkinlik artacaktır. Denetim çalışmalarında fiziksel bağımlılıktan, veriye ulaşımda yaşanan sorunlardan, planlamada meydana gelen son andaki olumsuz değişiklikten ve diğer katlanılması gereken bazı giderlerden kurtularak denetimin kalitesi artacaktır. Bu makalede Nİ kavramının muhasebe denetiminde stoklar döngüsüne uygulanmasına yönelik geleneksel yaklaşım ile Nİ yaklaşımları karşılaştırmalı olarak örneklerle sunulmuştur. Nİ kavramının yeni olması ve bu alanda daha önce bir çalışma olmaması nedeniyle, bu çalışmanın finansal tablolardaki diğer hesaplar için de genişletilerek yapılmasında yarar bulunmaktadır. Yapılacak yeni çalışmalar, şirketlerin ve bağımsız denetim kurumlarının kendilerini geleceğe hazırlamalarına 1şık tutacaktır.

Küresel rekabet üstünlüğü sağlamak amacıyla şirketler hızlı bir şekilde Nİnin uygulama olanaklarını araştırmakta ve geliştirmektedir. Nİnin gelişimini tamamlarken, sadece nesnelerin değil insanların da bu büyük ağa katılımı daha büyük yarar sağlayacaktır. Bu nedenle, Nİ kavramının ileride her şeyin interneti olarak evrimleşmesi beklenmektedir. 


\section{KAYNAKLAR}

AICPA, Amerikan Diplomalı Kamu Muhasebeciler Enstitüsü. (www.aicpa.org/)

Ashton, Kevin (2009), “That Internet Of Things”, RFID Journal, 22.6.2009 (http://www.rfidjournal.com/articles/view?4986, 27.01.2017).

Atzori, Luigi - Iera, Antonio - Morabito, Giacomo (2010), “The Internet Of Things: A Survey", Computer Networks, 54, ss. 2787-2805.

Baheti, Radhakisan - Gill, Helen (2011), "Cyber-Physical Systems”, The Impact Of Control Technology, Samad, Tariq - Annaswamy, Anuradha (Eds.), IEEE Control Systems Society. (www.ieeecss.org, 15.07.2016).

Baysan, Suat (2016), Sayısal Kendin Dönemi Geliyor, ICT Media. (http://ictmedia.com.tr/magazine/2016/01/files/assets/basic-html/page8.html, 04.17.2016).

Bozkurt, Nejat (2006), Muhasebe Denetimi, Alfa: İstanbul.

Burges, Matt (2016), How Google's AI Taught Itself To Create Its Own Encryption, Wired, 31.10.2016. (http://www.wired.co.uk/article/google-artificial-intelligence-encryption, 21.12.2016).

Chui, Michael. - Löffler, Markus - Roberts, Roger (2010), "The Internet Of Things", McKinsey Quarterly, 2, ss. 1-9.

Cohen, Robert B. (2016), Case Studies On How IoT Helps Firms Optimize Their Digital Performance And How IoT Will Have A Large Economic Impact In The Future, Internet Of Things Conference, 28 April 2016.

Çapa, Emin (2016), Dijital Sanayi, CNN Türk, 02.12.2016. (http://www.cnnturk.com/tv-cnnturk/programlar/dijital-sanayi/bir-fabrika-nasil-ve-ne-zaman-akilli-olur-emin-capaanlatti, 10.01.2017).

Dai, Y.H. - Ge, X.Y. (2015), "Optimization Of Internal Accounting Control Based On The Internet of Things", Management, Information and Educational Engineering: Proceedings of the 2014 Conference, 22-23 November 2014 China, ss. 55-59.

Duda, Giray (2015), “4. Sanayi Devrimi”, Global Sanayici Aylık Ekonomi ve İş Dünyası Dergisi, 10.08.2015. (http://www.sanayicidergisi.com/ayin-dosyasi/4-sanayi-devrimiuretimin-her-asamasinin-dijitallesmesi-demek.htm, 27.01.2017).

EP, European Parliament, (2015), Industry 4.0, Briefing, September 2015. (http://www.europarl.europa.eu/RegData/etudes/BRIE/2015/568337/EPRS_BRI(2015 )568337_EN.pdf, 14.10.2016).

GE General Electrics (2015), Endüstriyel İnternet, Ak1llı Makineler ve Yeni bir Ekonomi, GE, 23.11.2015. (http://geturkiyeblog.com/endustriyel-internet-akilli-makineler-veyeni-bir-ekonomi/, 25.11.2016). 
Guillemin, Patrick - Friess, Peter (2009), Internet of Things: Strategic Research Roadmap, European Research Project, 15.09.2009. (http://sintef.biz/upload/IKT/9022/CERPIoT\%20SRA_IoT_v11_pdf.pdf, 16.07.2016).

Güredin, Ersin (2000), Denetim, Beta: İstanbul.

Heil, Andreas - Knoll, Mirko - Weis, Torben (2007), The Internet of Things - Context-based

Device Federations, in Proceedings of the 40th Annual Hawaii International Conference on System Sciences.

Heilbroner, Robert L. - Milberg, William (2011), The Making of Economic Society, 13th Ed., Pearson: England.

Kahraman, Hakan (2016), “Kendinden Organize Dijital Fabrikalar”, Türkiye'nin Endüstri 4.0 Platformu, 14.02.2016. (http://www.endustri40.com/kendinden-organize-dijitalfabrikalar/, 08.08.2016).

Kaval, Hasan (2008), Muhasebe Denetimi, Gazi: Ankara.

KGK, Kamu Gözetimi Kurumu, Bağımsız Denetim Standartları (BDS), “İşletme ve Çevresini Tanımak Suretiyle ‘Önemli Yanlışlık' Risklerinin Belirlenmesi ve Değerlendirilmesi 315", "Bağımsız Denetim Kanıtları 500", "Analitik Prosedürler 520", Türkiye Denetim Standartları (International Auditing and Assurance Standards Board).

Leary, Daniel E. (2013), "Big Data, The Internet of Things and The Internet of Signs", Intelligent Systems in Accounting, Finance and Management, 20, ss.53-65.

Muller, Joann (2012), "With Driverless Cars, Once Again It Is California Leading The Way", Forbes, (http://www.forbes.com/sites/joannmuller/2012/09/26/with-driverless-carsonce-again-it-is-california-leading-the-way/\#28b0f507aaca, 24.11.2016).

Ning, Huansheng - Hu, Sha (2012), "Technology Classification, Industry, And Education For Future Internet Of Things", International Journal of Communication Systems, 25(9), ss. $1230-1241$.

Özhan, Tarkan (2016), Makinelerin Evrimi 4. Sanayi Devrimi, Ekitap Projesi.

Rifkin, Jeremy (2015), Nesnelerin İnterneti ve İşbirliği Çağı, İletişim Yayınları: İstanbul.

Sarı, Hilal (2016), İnsansız Fabrikalar 30 Yılda Türkiye'de, Dünya, (www.dunya.com/ekonomi/insansiz-fabrikalar-30-yilda-turkiyede-haberi-308675, 24.09.2016).

Selimoğlu, Seval - Özbirecikli, Mehmet - Uzay, Şaban - Uyar, Süleyman (2015), Bağımsız Denetim, Türmob Yayınları: Ankara.

Singh, Jatinder - Pasquier, Thomas - Bacon, Jean - Ko, Hajoon - Eyers, David (2016), "Twenty Security Considerations For Cloud-Supported Internet Of Things", IEEE Internet Of Things Journal, 3(3), ss. 269-284.

TBMM (2016), 6698 Sayılı Kişisel Verilerin Korunması Kanunu (https://www.tbmm.gov.tr/kanunlar/k6698.html, 15.10.2016). 
Yüksek, Y.S. Selim (2015), "Bilim Teknolojileri ve Değerler, Firsatlar ve Riskler", Medeniyet İnşası Türkiye Vizyonu Uluslararası Kongresi, 05-06 Kasım 2015, İstanbul. (http://bs.org.tr/arastirma-makale/nesnelerin-interneti-internet-of-things-vedegerler-konferans/544, 27.01.2017).

Zanella Andrea - Vangelista, Lorenzo (2014), "Internet Of Things For Smart Cities," IEEE Internet Things Journal, 1(1), ss. 22-32. 